\title{
Regulatory Region Mutation
}

National Cancer Institute

\section{Source}

National Cancer Institute. Regulatory Region Mutation. NCI Thesaurus. Code C148646.

A change in the nucleotide sequence of a regulatory region for a gene. 